\title{
The Role of Public Relations in Managing Messages in a Web Portal Study on Discourse Analysis of Cultural Hegemony on the Web Portal of the State-Owned Enterprises (SOE) Subsidiaries
}

\author{
Baskoro A. Pratomo ${ }^{1}$, Prof. Dr. Billy Sarwono, M.A. ${ }^{2}$ \\ Pascasarjana Departement Ilmu Komunikasi Universitas Indonesia, Gedung IASTH Lt. 6, \\ Kampus UI Salemba, JL. Salemba Raya No. 4 Jakarta \\ baskoropratomo@gmail.com¹, billysarwono@gmail.com²
}

\begin{abstract}
Indonesia, as one of the world's oil producers, needs fulfillment of its domestic oil supply. One of the strategies is the management transfer of the working areas in which the contract has expired. These working areas are subsequently managed by a State-Owned Enterprises (SOE) subsidiary that handles the energy sector. Problems arise when employees who are transferred have to adapt to the new organizational culture. The new organization uses various ways to educate new employees, one of which is using an internal web portal. The web portal contains the vision, mission, and organizational culture of the SOE that must be obeyed by members of the organization. In the text and visual of these BOD Messages, a tendency arises that the new organizational culture is superior to the old organizational culture. This study uses discourse analysis with the Systemic Functional Linguistic (SFL) method to dissect the text and visual in the BOD Messages.
\end{abstract}

Keywords: Systemic Functional Linguistic (SFL), Cultural Hegemony, Organizational Culture

\section{Introduction}

Indonesia is an oil and gas producing country in the world with proven reserves of 3 billion barrels for oil and 100 TCF for gas reserves. The need for oil and gas in his homeland continues to increase every year, so we need a strategy to deal with it. One of the strategies taken is to transfer management of the work area that has expired. Based on the Regulation of The Minister of Energy and Mineral Resources No. 15 of 2015, concerning "management of oil and gas working areas which will end their cooperation contracts," the Working Areas must be returned to the Indonesian government. Furthermore, the government offers the Working Areas to State-Owned Enterprises (SOE) in the energy sector, so that they can be managed well.

The process of management transfer is certainly not an easy matter due to the technical and non- technical factors that must be prepared therein. Technical factors relate to smooth production with indicators that there is no decrease in production during the process of management transfer. In contrast, non-technical factors relate to supporters when the transfer of management with indicators of the process of transfer of management can run smoothly, and there is no internal turmoil. Therefore, a communication strategy is needed to support the smooth process of the transfer of management.

For employees, transfer of management is not only related to changes in employment status 
but also changes in culture and organizational structure therein. Organizational change is a process in which the organization moves from the current conditions to the desired conditions to increase organizational effectiveness. Ideally, in an organizational structure, there is a flow of communication that creates a system and culture of its own within the organization. Members of the organization also carry information and culture from previous organizations that might not be able to escape when entering the new organization. This case/tendency is called as a cultural gap in the organization.

Furthermore, the new organization's culture and structure need to be socialized to new members of the organization. On the other hand, new members of the organization also need media to find out about the organization's culture and structure. This mutual need for information aims to achieve organizational effectiveness in which new members begin to recognize the new organization's role, and the organization feels that its new members have understood the direction, goals, vision, and mission of the company. One of them is the media to conduct socialization through a web portal on the internet.

Web portals are usually prepared by a department whose job is to process information entering and leaving the organization. In this case, the role of public relations is vital to manage the information. Making a web portal and other material must go through this department to comply with the management policies that are being carried out. In this web portal, there is a column called BOD (Board of Directors) Message, which is a column that contains information about management directives related to the current organizational situation. The BOD Message represents management's expectations of the organization's employees, including the delivery of the company's vision and mission as well as the organizational culture that is being socialized therein. In this study, the theme of the BOD Message taken was regarding the 12th anniversary of the organization.

If seen in more detail, this BOD Message consists of displaying text and visual appearance, which is then dissected using the "Systemic Functional Linguistic (SFL)" method. In carrying out this method, each text is dissected up to the clause stage, and then dissected again based on its metafunctions, namely ideational, textual, and interpersonal. Furthermore, after conducting dissection on metafunctions, this clause is analyzed by looking at the context of the situation and cultural context; in this case, the cultural context used is organizational culture. The purpose of conducting this dissection study is to find out whether there is a tendency to control the vision and mission of the organization to new members of the organization by studying the text or visual display in the BOD Message. In this case, the organization tries to do hegemony over the culture of the organization that has existed before.

\section{Theoretical Basis}

Organizational culture refers to the organization's fundamental values that are trusted to be accurate by all organization members for solving organizational problems. According to research conducted by Sri Indarti with the title the influence of Corporate social responsibility (CSR) and organizational culture on job satisfaction, the results show that State-Owned Entreprises (SOE) and Regional owned enterprises (ROE) focus more on a culture that is oriented to the external, namely adaptability and mission (Sri, 2008). According to Sackmann, an organizational culture concept is divided into 3 (three) perspectives, namely: holistic, variable and cognitive perspectives.

According to Schein, the key to understanding organizational culture is the correct 
understanding of socialization itself as a process of learning shared values and behavior patterns. This socialization process is not only limited to formal and explicit forms, but also includes activities implicitly and not systematically programmed. If the fundamental assumptions and core values of the culture have been accepted and become a pattern of shared behavior by most organization members, then it can be stated that it has a strong culture. In contrast, if it is the opposite, i.e., the members of the organization do not embrace and implement fundamental values, then that culture is called soft culture. In soft culture, the pattern of behavior is not based on trust and belief, so it is only a formality (Hardjana, 2013).

According to Peter J. Jackson, Corporate Communication is a communication activity produced by a company to obtain planned objectives. The intended purpose is a series of activities organized as a series of integrated campaigns and programs that take place on an ongoing and regular basis. The program is run not only for companies' externals but also for their internals (Thøger Christensen, 2002). The function of Corporate Communication is not only to build a positive image but also to convince internal companies to achieve organizational goals (Salihul Hadi, 2002).

Based on research conducted by R. R Dinar Soelistyowati on employees in SOE organizations, it was observed that organizational communication in SOEs runs well if there is a relationship between leaders and subordinates so that employee motivation can be achieved. Motivation from superiors to subordinates can encourage the achievement of targets, and organizational communication is needed in motivating employees' work (Soelistyowati, 2005)

A company/institution is an organization and part of the industry. The role of corporate communication is vital to the organization. The concept of corporate communication also has the same meaning as organizational communication because it has the same root word, so in fact, the two words are compatible and interchangeable (Purwandini, 2018). In this case, corporate communication is not only a tool but can be a phenomenon that can be learned in an organization (Ihlen et al., 2011). According to Dr. Arni Muhammad, there are 3 (three) essential points in terms of organizational communication, namely: organizational communication occurs in a complex open system and is influenced by its environment (both internal and external); Organizational communication includes messages and currents, goals, direction and media; and Organizational communication includes people and their attitudes, skills, and feelings.

Text and visual display can also be a medium for dominance over one ideology over another, commonly called hegemony. According to the Big Indonesian Dictionary (KBBI), hegemony is the influence of leadership, domination, and power of a country over other countries. Hegemony can also be interpreted as the dominance of one group over another without coercion. According to Antonio Gramsci, hegemony is a dominance of the values of life, social relations, morals, and cultural groups carried out by the authorities to the public. The dominance of a group is performed smoothly so that other groups do not feel oppressed and assume all of that is a natural thing (common sense) (Teori Hegemoni dalam Komunikasi Massa - PakarKomunikasi.com, n.d.).

Hegemony, according to Gramsci, emphasizes more on moral awareness where someone is made aware of the purpose of the hegemony. The process of the hegemony, according to Gramsci, is when a text or situation is interpreted in a certain way that promotes the interests of the group over other groups, to subvert the interests of the sub-ordinate group and support the dominant group. One way is by socializing narratives (Sifa, 2012). Hegemony emphasizes culture as a concept, since culture can act as a medium to distribute power and influence. 


\section{Research Methods}

This study uses a post-positivist paradigm with a qualitative approach to see phenomena in the text and visuals reflected in the BOD Message. The research strategy carried out refers to the Systemic Functional Linguistic (SFL) method of MAK Halliday by dividing a clause into metafunction. In this study, the subject was the submission of the BOD Message in the $12^{\text {th }}$ Anniversary edition of the organization. Thus the method of collecting data using document studies. Analyzing data is closely related to data collection and data interpretation. This research refers to discourse analysis with the SFL technique. Researchers divide the display into 2 (two) pieces, namely: text and images.

Then both of them are analyzed using existing metafunctions and breaking a sentence or image into a clause. Researchers, in this case, divide the research subject into three functions, namely ideational, interpersonal, and textual. After analyzing text and images, the researcher analyzes the context of the situation, which is divided into field of disclosure, tenor of disclosure and mode of disclosure. Next, the analysis continues with the context of culture. According to Malinowski, culture consists of artifacts inherited in the form of goods, technical processes, ideas, values, and habits. The cultural context also refers to the values shared by a group of people. Language is a reflection of people's culture, not only in vocabulary selection but also in syntax and ways of organizing ideas. As a writer, the results of the texts he/she makes are influenced by particular cultural backgrounds. Social Purpose aims to give meaning to the social activities that are being carried out (Imtihani, 2010).

\section{Analysis and Results}

The data that will be used in this study is 1 BOD Message data, which was published in December 2019. The data analyzed are BOD Message issued on company anniversary with the title "12 years PHE Together \& Unite". Furthermore, data consisting of texts and discourse are analyzed using Systemic Functional Linguistics theory to display an understanding of management messages to employees. Whereas visual data were analyzed using multimodality. With these 2 (two) methods, it is expected to provide an overview of management policies to employees based on models or an understanding of public relations.

Furthermore, the analysis is also seen based on the vision and mission of PT PHE. The vision of PT PHE is to become a world-class oil and gas company, while the mission is to carry out operations management $\&$ business portfolio of the upstream oil and gas sector in a professional and high-profit manner and provide added value to stakeholders. The text and image then attempted to be interpreted to see whether the text and the image adjust to the company's vision and mission.

Furthermore, the text and images are analyzed using the context of the situation and cultural context so that the results obtained are in the context of the situation, and there is an effort from management to socialize the vision and mission and culture of the organization because management feels that employees have not applied the organizational culture standards as requested. In this socialization activity, management uses formal language, only using a third pronoun, which means that all of us (members of the organization) have an obligation to fulfill the organization's vision, mission, and goals.

As for the cultural context, it is observed that the inculcation of organizational culture to members of the organization becomes essential because it involves the identity of the 
organization. This cultural cultivation applies to members who have just joined or members who have long joined. It is one of the goals of the organization to be more efficient. Efficiency is achieved if all organization members know their roles and responsibilities well within the organization, which causes the organization to run in line with one goal of achieving the company's vision and mission.

Cultural socialization is a process that runs continuously and systematically so that a communication strategy is needed therein. BOD Message is one of management's strategies to carry out cultural socialization to its employees. This socialization process itself is seen in situations where this text is delivered, namely as a state mandate that must be completed correctly and adequately. Furthermore, this pride must also be balanced with the demands of management to its employees so that they can pay attention to the company's vision and mission and the goals of the company itself. Another demand is perfection in doing work, given that the state's mandate makes the organization a national reference for similar industries.

The organization continues to conduct socialization both when it will enter the phase of transfer of management, and when it has become part of the organization. One form of socialization is carried out through the BOD Message. In the message delivered by the management, it was implied that there was an effort to display the pride of being a member of the organization, namely as part of an organization that received the mandate of the state in the industrial sector.

The fact is, the old companies / Working Areas that the management was taken over were formerly foreign companies with different cultures and work standards. However, the hegemony process itself occurred when the organization raised the message that being a member of the organization was complacency because it had become part of the mandate of the state. This message was socialized simultaneously and structured so that it slowly got rid of the previous organizational culture. Organizational members consciously or unconsciously have been hegemonized with the message, so they feel that there is no problem with the message's circulation.

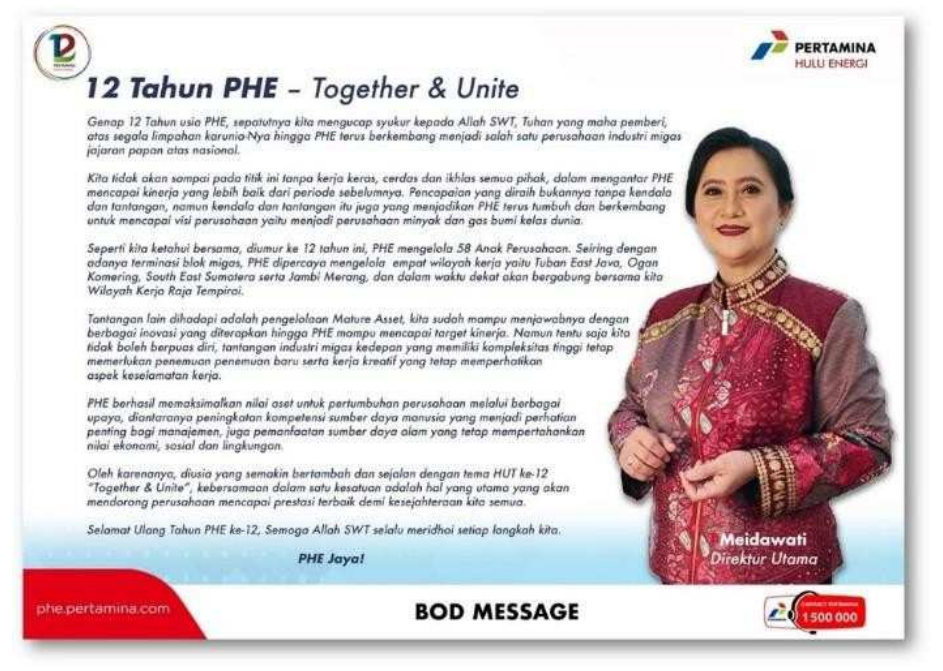




\section{References}

[1] Anggarina, P. T., \& Setyanto, Y. (n.d.). Media Sosial: Membangun Komunikasi Internal yang Konstruktif dalam Perusahaan. https://doi.org/10.1017/CBO9781107415324.004

[2] Breakenridge, D., \& DeLoughry, T. J. (2003). The New PR Toolkit: Strategies for Successful Media Relations.

[3] Chabibie, M. H. (2012). PENGARUH PENERIMAAN TEKNOLOGI DENGAN KEGUNAAN WEB (Studi Kasus Portal Rumah Belajar).

[4] Choerunnisa \& Yuniarti, T. (2015). Komunikasi internal humas pt pertamina (persero) dalam media energia weekly. 6.

[5] Detlor, B., Hupfer, M. E., Ruhi, U., \& Zhao, L. (2013). Information quality and community municipal portal use. Government Information Quarterly, 30(1), 23-32. https://doi.org/10.1016/j.giq.2012.08.004

[6] dilenschneider, R. L. (2010). AMA Handbook Public Relations Leveraging PR in the digital world. $\quad$ http://www.ghbook.ir/index.php?name= رسانه فن هنحنوين \&option=com_dbook\&task=readonline\&book_id=13650\&page=73\&chkhashk=ED9C9491 B 4\&Itemid=218\&lang $=$ fa\&tmpl=component

[7] Dirut Pertamina Curhat ke DPR, Minta Bantuan Muluskan Alih Kelola Blok Rokan dari Chevron - Dunia Energi. (n.d.). Retrieved June 11, 2020, from https://www.duniaenergi.com/dirut- pertamina-curhat-ke-dpr-minta-bantuan-muluskan-alih-kelola-blok-rokan-darichevron/

[8] Domingo, D., \& Ponti, E. (2014). Developing Public Relations 2 . 0 : Practitioners 'perceptions on the implementation of interactive communication strategies. Public Relations Review, 40(3), 559- 561. https://doi.org/10.1016/j.pubrev.2014.04.001

[9] Doorley J, Fred Garcia, H. (2015). Reputation Management The key to successful PR and Corporate Communication.

[10] Hardjana, A. A. (2013). Sosialisasi dan Dampak Budaya Organisasi. Jurnal ILMU KOMUNIKASI, 7(1), 1-40. https://doi.org/10.24002/jik.v7i1.194

[11] Huang, J., Baptista, J., \& Galliers, R. D. (2013). Reconceptualizing rhetorical practices in organizations: The impact of social media on internal communications. Information and Management, 50(2-3), 112-124. https://doi.org/10.1016/j.im.2012.11.003

[12] Imtihani, N. (2010). Genre Analysis in the Frame of Systemic. Humaniora, 22(1), 56-93.

[13] Ishak, A. (2012). Peran Public Relations dalam Komunikasi Organisasi. Jurnal ASPIKOM, 1(4), 373. https://doi.org/10.24329/aspikom.v1i4.38

[14] Nam, J. (2014). Understanding the motivation to use web portal. Encyclopedia of Special Education, 36, 263-273. https://doi.org/10.1002/9781118660584.ese0548

[15] Oliver, S., \& Chartered Institute of Public Relations. (2010). Public relations strategy. 188.

[16] Petrovici, M. A. (2014). E-Public Relations: Impact and Efficiency. A Case Study. Procedia Social and Behavioral Sciences, 141, 79-84. https://doi.org/10.1016/j.sbspro.2014.05.015

[17] PHE Targetkan Lifting Migas Tahun Depan Capai 181.510 BOEPD - Berita Katadata.co.id. (n.d.). Retrieved June 11, 2020, from https://katadata.co.id/berita/2019/12/13/phe-targetkanlifting- migas-tahun-depan-capai-181510-boepd

[18] RATNA SARI, Y. (2017). Representasi identitas Ideologis Hillary Clinton dan Donald Trump Dalam Debat Presiden Amerika Serikat 2016: analisis wacana kritis.

[19] Sifa, S. (2012). Representasi Identitas Budaya Amerika dan Imigran dalam Film Produksi Amerika (Analisis Semiotika Film Spanglish).

[20] Teori Hegemoni dalam Komunikasi Massa - PakarKomunikasi.com. (n.d.). Retrieved June 13, 2020, from https://pakarkomunikasi.com/teori-hegemoni-dalam-komunikasi-massa

[21] Thøger Christensen, L. (2002). Corporate communication: The challenge of transparency. Corporate Communications: An International Journal, 7(3), 162-168. https://doi.org/10.1108/13563280210436772 